\title{
GENOTOXIC EVALUATION OF NEWLY SYNTHESIZED ORGANOMETALLIC COMPOUNDS OF TIN
}

\author{
DAMATI A. ${ }^{1}$ \\ VLASTOS D. ${ }^{1}$ \\ PHILIPPOPOULOS A.I. ${ }^{2}$ \\ MATTHOPOULOS D.P. ${ }^{1, *}$
}

Received: $27 / 02 / 2015$

Accepted: $11 / 05 / 2015$

Available online: $26 / 08 / 2015$

\author{
${ }^{1}$ Department of Environmental and Natural Resources Management \\ University of Patras, Seferi 2, Agrinio 30100, Greece \\ ${ }^{2}$ Faculty of Chemistry, National and Kapodistrian University of Athens \\ Athens, Greece
}

*to whom all correspondence should be addressed: e-mail: dmatthop@upatras.gr

\section{ABSTRACT}

The genotoxic effects of organometallic tin(II) and tin(IV) complexes namely $\mathrm{L}_{\mathrm{OEt}} \mathrm{SnCl}(\mathbf{5}), \mathrm{L}^{*}{ }_{\mathrm{OEt}} \mathrm{SnCl}(\mathbf{6})$, $\mathrm{L}_{\mathrm{OEt}} \mathrm{SnPh}_{3}(7), \mathrm{L}^{*}{ }_{\mathrm{OEt}} \mathrm{SnPh}_{3}(8)$, incorporating the oxygen tripodal ligands $\left[\left(\eta^{5}-\mathrm{C}_{5} \mathrm{R}_{5}\right) \mathrm{Co}\left\{\mathrm{P}(\mathrm{OEt})_{2} \mathrm{O}\right\}_{3}\right]^{-},\{\mathrm{R}=\mathrm{H}$, $\left(\right.$ LoEt $\left.\left.^{-}\right)(3) ; \mathrm{R}=\mathrm{Me}\left(\mathrm{L}^{*} \mathrm{OEt}^{-}\right)(4)\right\}$ (Klaui type ligands), were investigated using the Cytokinesis Block Micronucleus assay in human lymphocytes cultures. For comparison the precursors $\operatorname{NaL}_{\mathrm{OEt}}(3), \mathrm{NaL}^{*} \mathrm{OEt}_{(4)}$, $\mathrm{SnCl}_{2} \cdot 2 \mathrm{H}_{2} \mathrm{O}(\mathbf{1})$ and $\mathrm{Ph}_{3} \mathrm{SnCl}(2)$, were also studied.

Statistically significant differences in comparison with the control in the micronuclei frequencies were seen at the concentrations: $75 \mu \mathrm{M}$ for complex (5), $50 \mu \mathrm{M}$ for complex (6), 20, 50, $75 \mu \mathrm{M}$ for complex (8). No statistically significant differences were observed between controls and all the rest tested concentrations for all chemicals examined.

The cytotoxic effect was evaluated by the Cytokinesis Block Proliferation Index. Regarding this index, the precursor (1) is not cytotoxic at all tested concentrations. Complexes (3), (4) and (5) induced cytotoxicity at the concentrations of 20,50 and $75 \mu \mathrm{M}$, while complexes (6) and (8) were cytotoxic at all tested concentrations. Complex (7) was cytotoxic at 5, 10 and $20 \mu \mathrm{M}$ but extremely toxic at 50 and $75 \mu \mathrm{M}$. Finally complex (2) was extremely toxic at all tested concentrations except at $1 \mu \mathrm{M}$.

Keywords: Cytotoxicity, Cytokinesis Block Micronucleus assay, Genotoxicity, Klaui ligands, Organotin compounds

Abbreviations: Binucleated (BN) cells, Cytochalasin-B (Cyt-B), Cytokinesis Block Micronucleus (CBMN), Cytokinesis Block Proliferation Index (CBPI), Dimethyl sulfoxide (DMSO), Micronuclei (MN), Mitomycin-C (MMC)

\section{Introduction}

Organotin complexes displaying typical metal to carbon single bonds $(\mathrm{Sn}-\mathrm{C})$ represent an important class

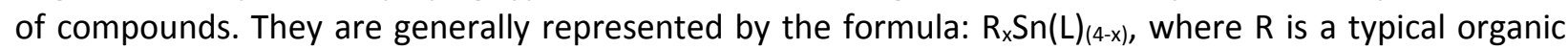
group such as methyl, butyl, octyl, etc. For the organotin stabilizers and catalysts, $x$ is either 1 or 2 , while for organotin biocides and pesticides, $x$ equals to 3 and the R group is usually a butyl, cyclohexyl or phenyl group. Once these compounds are made and isolated, the R groups maintain their connection to tin; they do not transfer from one tin to another under normal conditions of use. Organotin compounds present a broad range of industrial applications such as PVC stabilizers, catalysts, biocides and pesticides,

Damati A., Vlastos D., Philippopoulos A.I. and Matthopoulos D.P. (2015), Genotoxic evaluation of newly synthesized organometallic compounds of tin, Global NEST Journal, 17(3), 574-582. 
intermediates in chemical synthesis, antifouling paints, glass coverings and veterinary as well as human medicines (Greenwood and Earnshaw, 1997; Appel, 2004; Government of Canada, 2010).

The toxicity of inorganic forms of tin toward microorganisms is relatively low, but the more lipid soluble organotins are thought to be more toxic (Cima et al., 2003). Tri-substituted ( $\left.R_{3} S n X\right)$ organotins were reported to be more toxic than di- $\left(\mathrm{R}_{2} \mathrm{SnX} \mathrm{X}_{2}\right)$ and mono-substituted $\left(\mathrm{RSnX}_{3}\right)$ compounds, while the anion $\left(X^{-}\right)$appeared to have little influence on the toxicity of the tin compound (Gadd, 2000).

In a standard battery of tests, pesticidal organotin compounds are generally negative although some have been shown to be genotoxic (Jensen et al., 1991; Sasaki et al., 1993). In vitro exposure of human lymphocytes to organotin compounds resulted in statistically significant increases in the frequency of hyperdiploid cells. Indications pointed that some organotin compounds were able to induce aneuploidy in human peripheral lymphocytes in vitro, probably by affecting spindle function (Jensen et al., 1991). In the meantime there were reports that tributyltin and triphenyltin compounds increase the frequency of chromosome aberrations in Chinese hamster ovary cells (CHO-K1) (Sasaki et al., 1993). Mutagenicity studies of several organotin compounds, including butyltin, phenyltin and methyltin derivatives, as well as the inorganic tin tetrachloride, were performed using the Salmonella mutagenicity assay (Ames test) (Hamasaki et al., 1993).

Trimethyltin chloride induced micronuclei (MN) and chromosome aberrations in healthy male and female human lymphocytes (Ghosh et al., 1990; Ghosh et al., 1991). Isolated lymphocytes of different age groups were exposed to two concentrations of trimethyltin chloride $\left(0.1\right.$ and $\left.0.2 \mu \mathrm{g} \mathrm{m}^{-1}\right)$. In this study, the lower concentration of trimethyltin chloride induced more micronucleated cells than did the higher dose, and male individuals showed higher frequencies of $\mathrm{MN}$ than female ones. No correlation between MN frequencies and donor age was observed. However, evidence was provided that butyltin compounds significantly inhibiting apoptosis in human cells (Whalen et al., 1999).

The potential of organometallic compounds of tin for adversely affecting animal and human health is well documented. Nevertheless, data on the genotoxicity as well as on the mechanisms of cellular action of organotin compounds are scarce (Penninks and Seinen, 1984; Gielen, 2003; Chasapis et al., 2004; Dopp et al., 2004; Tabassum and Pettinari, 2006).

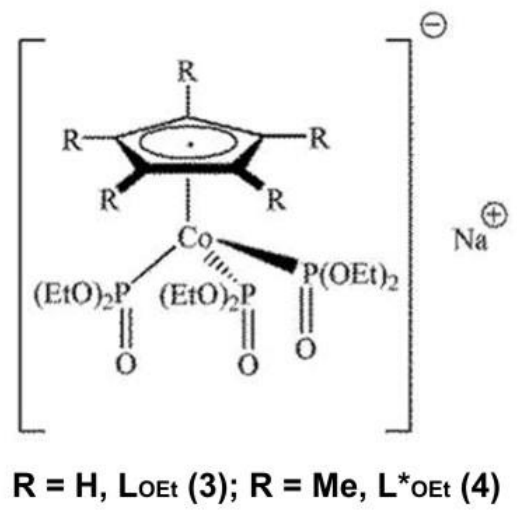

Figure 1. The molecular structure of $\mathrm{NaL}_{\mathrm{OEt}}(\mathbf{3})$ and $\mathrm{NaL}^{*}{ }_{\mathrm{OEt}}(\mathbf{4})$.

Design and biological evaluation of new organometallic tin compounds is an issue of current research (Gielen et al., 2005; Basu Baul, 2008; Hadjikakou and Hadjiliadis, 2009; Pizarro et al., 2010). In this respect a series of organometallic tin(II) and tin(IV) complexes incorporating the oxygen tripodal ligands [ $\eta^{5}$ $\left.\left.\mathrm{C}_{5} \mathrm{R}_{5}\right) \mathrm{Co}\left\{\mathrm{P}(\mathrm{OEt})_{2} \mathrm{O}\right\}_{3}\right]^{-},\left\{\mathrm{R}=\mathrm{H},\left(\mathrm{LOEt}^{-}\right)(3) ; \mathrm{R}=\mathrm{Me}\left(\mathrm{L}^{*} \mathrm{OEt}^{-}\right)(4)\right\}$ (Fig. 1) were synthesized, according to a previously described procedure followed for the synthesis of the germanium(II) analogues (Filippou et al., 2000). The four-coordinate $\mathrm{LoEt}_{\mathrm{OSnCl}}(5)$ and $\mathrm{L}^{*}{ }_{\mathrm{OEt}} \mathrm{SnCl}(6)$ chlorides were obtained by a metathetical exchange reaction of $\mathrm{SnCl}_{2}$ with the starting materials (3) and (4). The corresponding six-coordinated tin(IV) derivatives $\mathrm{L}_{\mathrm{OEt}} \mathrm{SnPh}_{3}(\mathbf{7})$ and $\mathrm{L}^{*}{ }_{\mathrm{OEt}} \mathrm{SnPh}_{3}$ (8) were formed from the reaction of the $\mathrm{Ph}_{3} \mathrm{SnCl}(\mathbf{2})$ 
precursor with (3) and (4) respectively. The choice of the ligand is based on the chemical inertness of these ligands along with their thermal and hydrolytic stability, which is of crucial importance especially in the field of organometallic chemistry (Klaui et al., 1987).

In the present genotoxicity study, the Cytokinesis Block Micronucleus (CBMN) assay was employed for the detection of $\mathrm{MN}$ in the cytoplasm of interphase cells, under the influence of various concentrations of the four newly synthesized organotin compounds (5), (6), (7) and (8) and their precursors $\mathrm{SnCl}_{2} \bullet 2 \mathrm{H}_{2} \mathrm{O}(1)$, $\mathrm{Ph}_{3} \mathrm{SnCl}(2),(3)$ and (4).

$\mathrm{MN}$ may originate from acentric chromosome fragments or whole chromosomes that are unable to migrate towards the poles during the anaphase stage of cell division. The simplicity, rapidity, sensitivity as well as the validation of the CBMN assay renders it a valuable tool for genotoxicity screening. The assay detects the potential clastogenic and aneugenic activity of chemicals in cells that have undergone cell division after exposure to chemicals under investigation. The use of cytochalasin- $B$, an inhibitor of actin polymerization, which prevents cytokinesis, while permitting nuclear division leads to formation of binucleated (BN) cells which are scored for the presence of MN. OECD acceptance of the in vitro MN test led to its widespread international application (OECD, 2014).

Taken into consideration the previously described reasons, in this study, we aimed to comparatively investigate the cytotoxic and genotoxic effects of the four new organometallic compounds of tin using the CBMN assay in human lymphocytes cultures.

\section{Methodology}

\subsection{Chemicals}

The new organometallic tin(II) and (IV) compounds comprise the amphiphilic spectator ligands (3) and (4) described previously (see introduction). The ligands are abbreviated as NaLoet (3) for the case that the $R$ group of the cyclopentadienyl ligand is hydrogen (Klaui, 1979) and NaL* ${ }_{\text {oEt }}(\mathbf{4})$ where $\mathrm{R}=\mathrm{Me}$ (Roman et al., 1986; Klaui et al., 1997).

All chemicals were synthesized by Assist. Prof. A. I. Philippopoulos (Faculty of Chemistry, National and Kapodistrian University of Athens) in collaboration with Prof. Dr. A. C. Filippou (University of Bonn, Department of Chemistry) (paper under preparation) were of high purity ( $\geq 98 \%$ in solid state checked by elemental analysis and by multinuclear NMR spectroscopy in solution). All tested chemicals were dissolved in DMSO following the OECD (2014) guideline for testing of chemicals with the in vitro mammalian cell micronucleus assay as well as the Human micronucleus project (Bonassi et al., 2001).

Stannus chloride dehydrate (CAS no.: 10025-69-1) and triphenyl tin chloride (CAS no: 639-58-7) were obtained from Sigma-Aldrich Chemie GmbH (Steinheim, Germany).

\subsection{CBMN assay in human lymphocytes in vitro}

Blood samples were obtained from two non-smoking healthy young individuals not undergoing any drug treatment, viral infection or X-ray exposure in the recent past. Blood donors were aware of the present study that was conducted according to the University of Patras Ethics Committee and gave their consent.

Blood samples were kept under sterile conditions in heparinized tubes. Whole blood $(0.5 \mathrm{ml})$ was added to $6.5 \mathrm{ml} \mathrm{Ham}$ 's F-10 medium (Gibco, Grand Island, NY), $1.5 \mathrm{ml}$ foetal bovine serum (Gibco) and $0.3 \mathrm{ml}$ phytohaemagglutinin (Gibco) to stimulate cell division.

The various chemical solutions were added to final concentrations of $1,5,10,20,50$ and $75 \mu \mathrm{M}$. All tested chemicals were dissolved in DMSO. DMSO concentration in cultures did not exceed $0.75 \%$. The appropriate solutions were added $41 \mathrm{~h}$ post culture initiation. For each tested chemical, two identical sets in two independent experiments were conducted for all aforementioned concentrations as well as for positive and negative controls. The reported results represent the pooled data from the two donors' replicated cultures. 
Mitomycin-C (MMC) (Sigma-Aldrich Chemie $\mathrm{GmbH}$ ) at final concentration of $1.5 \mu \mathrm{M}$ served as positive control in all respective experiments (Stivaktakis et al., 2010). Subsequently, $3 \mathrm{~h}$ after the addition of the appropriate chemical solutions, $6 \mu \mathrm{g} \mathrm{ml}^{-1}$ Cytochalasin-B (Cyt-B) (Sigma) were added to the culture medium, at $44 \mathrm{~h}$ post culture initiation. This concentration of Cyt-B was selected so as to obtain a higher percentage of $B N$ cells and a lower baseline $M N$ frequency (OECD, 2014).

Cultures were incubated at $37{ }^{\circ} \mathrm{C}$ in a humidified $5 \% \mathrm{CO}_{2}$ atmosphere. $72 \mathrm{~h}$ after the initiation of culture, cells were harvested and collected by centrifugation. Collected cells were processed according to standard protocol (OECD, 2014) with minor modifications. A mild $3 \mathrm{~min}$, at room temperature, hypotonic treatment with $75 \mathrm{mM} \mathrm{KCl}$ was followed by 10 min fixation (for at least 3 times) with a fresh 3:1 solution of methanol/acetic acid before the cells were stained with $7 \%$ Giemsa.

In total, $4000 \mathrm{BN}$ cells with preserved cytoplasm scored per experimental point. Standard criteria were used for scoring MN (Fenech et al., 2003).

\subsection{Cytotoxicity evaluation}

In order to determine possible cytotoxic effects, the Cytokinesis Block Proliferation Index (CBPI) was calculated by counting at least 2000 cells for each experimental point (500 cells per culture of each donor). CBPI is given by the equation: $C B P I=\left[M_{1}+2 M_{2}+3\left(M_{3}+M_{4}\right)\right] / N$ where $M_{1}, M_{2}, M_{3}$ and $M_{4}$ correspond to the numbers of cells with one, two, three and four nuclei and $\mathrm{N}$ is the total number of cells (Surrales et al., 1995).

\subsection{Statistical analysis}

All results are expressed as the mean frequency $(\% \circ) \pm$ standard error $[\mathrm{MF}(\%) \pm$ se]. The statistical analysis of the obtained data was conducted with the use of the Minitab statistical software (Minitab Inc., Pennsylvania, USA) and the SPSS Inc.17. MN data analysis was conducted using the $G$-test for independence on $2 \times 2$ tables, while CBPI data set was analyzed using the chi-square $\left(\chi^{2}\right)$ test. Significant levels were established as $p<0.05$ in all cases.

\section{Results}

\subsection{Cytokinesis-block micronucleus (CBMN) assay}

Complexes (5-8) have been tested for the possible inductions of MN frequencies, while precursors (1-4) were used as controls in order to evaluate whether the observed effects resulted or not from the chemicals under investigation.

As positive control Mitomycin-C (MMC) at final concentration of $1.5 \mu \mathrm{M}$ was used. The positive control frequencies of $\mathrm{MN}(63.75 \pm 16.25 \%$ o) in our experiments are in accordance with published values in the used cytogenetic end point (Clare et al., 2006).

The results of $\mathrm{MN}$ analysis (mean values for $\mathrm{MN}$ induction as well as for CBPI) obtained from human peripheral blood lymphocyte cultures treated with different concentrations $(1,5,10,20,50$ and $75 \mu \mathrm{M})$ of the studied chemicals $(\mathbf{1}, \mathbf{3}, \mathbf{4}, \mathbf{5}, \mathbf{6}, \mathbf{7}, \mathbf{8})$ are shown in Figure 2 (a-g).

$\mathrm{Ph}_{3} \mathrm{SnCl}(2)$ was extremely cytotoxic towards the lymphocytes from the concentration of $5 \mu \mathrm{M}$, thus no histogram could be produced.

The mutagenic potential of the various compounds examined is depicted in Table 1. A comparative analysis of the genotoxicity of the various compounds, in the tested concentrations, points that the precursors $\mathrm{SnCl}_{2} \bullet 2 \mathrm{H}_{2} \mathrm{O}(\mathbf{1}), \mathrm{NaLOEt}_{(3)}$ and $\mathrm{NaL}^{*}{ }_{\mathrm{OEt}}(\mathbf{4})$ do not induce MN frequencies (no genotoxic effect) towards human peripheral blood lymphocytes. Statistically significant differences $(p<0.05)$ in comparison with the control in the $\mathrm{MN}$ frequencies were seen only at the higher tested concentration of (5) (75 $\mu \mathrm{M})$ as well as at the concentration of $50 \mu \mathrm{M}$ of (6), while (6) at the highest concentration (75 $\mu \mathrm{M})$ was lethal for the lymphocytes. In this respect, complex (7) was not genotoxic at the concentrations of 1, 5, 10 and $20 \mu \mathrm{M}$. However complex (7) appeared to be lethal for the lymphocytes at 50 and $75 \mu \mathrm{M}$. Finally, complex 
(8) revealed statistically significant differences $(p<0.05)$ in comparison with the control in the $\mathrm{MN}$ frequencies at 20,50 and $75 \mu \mathrm{M}$.

\subsection{Cytotoxic index evaluation}

The cytotoxic effect was evaluated by the CBPI index. Regarding this index, as can be seen in Figure 2, compounds (3), (4), and (5) at 20,50 and $75 \mu \mathrm{M}$, while compound (6) induced statistically significant decrease $(p<0.001)$ on CBPI values at all tested concentrations except of the $75 \mu \mathrm{M}$ where no cells could be observed, possibly due to extremely toxic effect. Compound (7) induced statistically significant decrease $(p<0.001)$ on CBPI values at the concentrations of 5,10 and $20 \mu \mathrm{M}$, while it was lethal at the 50 and $75 \mu \mathrm{M}$ concentrations. In the meantime compound (8) induced statistically significant decrease $(\mathrm{p}<0.001)$ on CBPI values at all tested concentrations. $\mathrm{SnCl}_{2} \bullet 2 \mathrm{H}_{2} \mathrm{O}(\mathbf{1})$ did not exert cytotoxic effect at all tested concentrations as it can be seen in Figure $2 . \mathrm{Ph}_{3} \mathrm{SnCl}$ (2) was apparently extremely toxic to lymphocytes except at the concentration of $1 \mu \mathrm{M}$, thus no histogram could be drawn and presented.

The cytotoxicity results in comparison to the genotoxicity ones are summarized in Table 1.
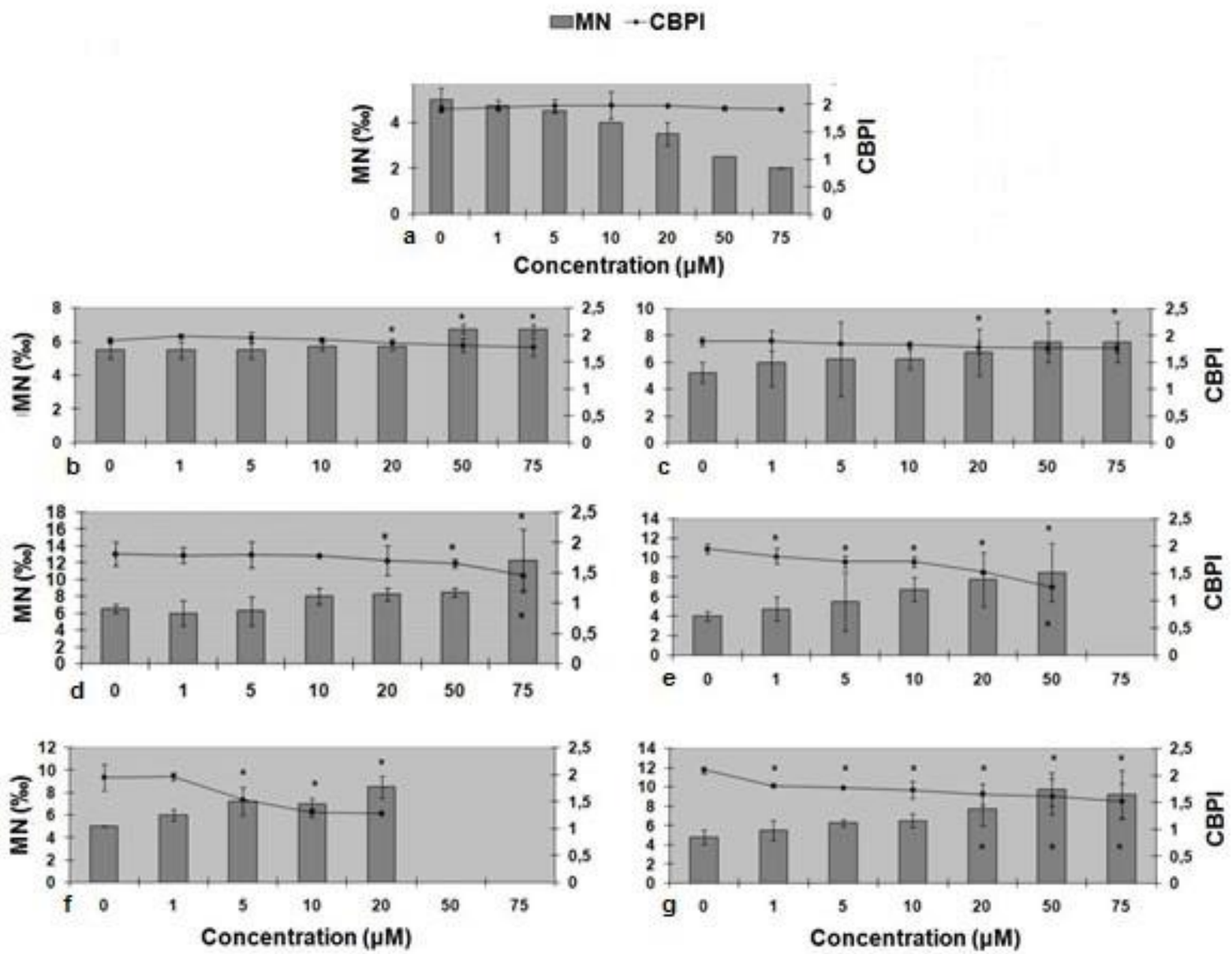

Figure 2. Induction of $\mathrm{MN}$ and $\mathrm{CBPI}$ values in human lymphocytes treated with a. $\mathrm{SnCl} 2 \cdot 2 \mathrm{H} 2 \mathrm{O}$ (1), b. NaLOEt (3), c. NaL*OEt (4), d. LOEtSnCl (5), e. L*OEtSnCl (6), f. LOEtSnPh3 (7) and g. L*OEtSnPh3 (8). 4000 binucleated cells scored per experimental point, ${ }^{*} p<0.05$ [G-test for MN]; ${ }^{*} p<0.001$ [x2 for CBPI

\section{Discussion}

Based on the broad range of industrial applications of organotin complexes (Greenwood and Earnshaw, 1997; Appel, 2004; Government of Canada, 2010) new organotin compounds are continuously 
synthesized and their antitumor and cytotoxic potential is under investigation (Shpakovsky et al., 2014; Zhao et al., 2014; Khan et al., 2014). The synthesis of a series of organotin complexes with Sn-S bonds of formulae $\mathrm{Me}_{2} \mathrm{Sn}(\mathrm{SR})_{2}$ (1); $\mathrm{Et}_{2} \mathrm{Sn}(\mathrm{SR})_{2}$ (2); $(n-\mathrm{Bu})_{2} \mathrm{Sn}(\mathrm{SR})_{2}$ (3); $\mathrm{Ph}_{2} \mathrm{Sn}(\mathrm{SR})_{2}$ (4); $\mathrm{R}_{2} \mathrm{Sn}(\mathrm{SR})_{2}$ (5); $\mathrm{Me}_{3} \mathrm{SnSR}(6)$; $\mathrm{Ph}_{3} \mathrm{SnSR}$ (7) ( $\mathrm{R}=3$,5-di-tert-butyl-4-hydroxyphenyl) that derived from the precursor $\mathrm{R}_{2} \mathrm{SnCl}_{2}$ (8) was reported and the in vitro cytotoxicity was investigated against normal human fetal lung fibroblast cells (MRC-5), as well as against human breast (MCF-7) and human cervix (HeLa) adenocarcinoma cells (Shpakovsky et al., 2014). Complexes 2 - 4 and 8 exhibited significantly lower cytostatic activity against the normal MRC-5 cell line compared to the tumor cell lines MCF-7 and HeLa. A high activity against both cell lines $250 \mathrm{nM}$ (MCF-7) and $160 \mathrm{nM}$ (HeLa) was determined for the triphenyltin complex 7 while the introduction of hindered phenol groups decreases the cytotoxicity of the complexes against normal cells. In the meantime twenty one novel mixed ligand di-n-butyltin(IV) complexes [ $n$-Bu $\mathrm{B}_{2} \mathrm{SnAL}$ ( $\mathrm{A}=$ substituted 4-acyl-5-pyrazolone, and $\mathrm{L}=$ fluorinated benzoic acid) were synthesized and their cytotoxicity against Hela and KB cancer cell lines compared to cisplatin was studied by means of the 3-(4,5-dimethyl-2-thiazolyl)2,5diphenyl-2H-tetrazolium bromide (MTT) assay (Zhao et al., 2014). All twenty one synthesized complexes were found more effective than cisplatin. Additionally, triorganotin(IV) complexes with six different $R \mathrm{~N}$-2-X-benzohydroxamic acid ligands having general formula $R^{\prime} \mathrm{C}(\mathrm{O}) \mathrm{N}(R \mathrm{~N}) \mathrm{OH}\left(R^{\prime}=\right.$ alkyl/aryl; $R \mathrm{~N}$ $=$ alkyl/aryl or $\mathrm{H}),\left(\mathrm{X}=-\mathrm{I},-\mathrm{NO}_{2},-\mathrm{OCH}_{3},-\mathrm{Br}\right.$ and $\mathrm{R}=-\mathrm{CH}_{3},-\mathrm{C}_{6} \mathrm{H}_{5}$ and $-\mathrm{C}_{6} \mathrm{H}_{4}-\mathrm{CH}_{3}$ ) were synthesized (Khan et al., 2014). They showed significantly higher cytotoxic activities than doxorubicin toward K-562, Jurkat, HepG2 and L929 cells using the MTT assay.

Table 1. Comparison of the genotoxic and cytotoxic action of the tested chemicals

\begin{tabular}{|c|c|c|c|c|c|c|c|c|c|c|c|c|}
\hline \multirow{3}{*}{ Compounds } & \multirow{2}{*}{\multicolumn{6}{|c|}{$\begin{array}{c}\text { Genotoxicity } \\
\text { Concentration }(\mu \mathrm{M})\end{array}$}} & \multicolumn{6}{|c|}{ Cytotoxicity } \\
\hline & & & & & & & \multicolumn{6}{|c|}{ Concentration $(\mu \mathrm{M})$} \\
\hline & 1 & 5 & 10 & 20 & 50 & 75 & 1 & 5 & 10 & 20 & 50 & 75 \\
\hline $\mathrm{SnCl}_{2} \cdot 2 \mathrm{H}_{2} \mathrm{O}(1)$ & - & - & - & - & - & - & - & - & - & - & - & - \\
\hline $\mathrm{Ph}_{3} \mathrm{SnCl}(2)$ & - & $\mathrm{NC}$ & $\mathrm{NC}$ & $\mathrm{NC}$ & $\mathrm{NC}$ & $\mathrm{NC}$ & - & NC & $\mathrm{NC}$ & $\mathrm{NC}$ & $\mathrm{NC}$ & $\mathrm{NC}$ \\
\hline $\mathrm{NaL}_{\mathrm{OEt}}(\mathbf{3})$ & - & - & - & - & - & - & - & - & - & + & + & + \\
\hline $\mathrm{NaL}_{\text {OEt }}(4)$ & - & - & - & - & - & - & - & - & - & + & + & + \\
\hline L & - & - & - & - & - & + & - & - & - & + & + & + \\
\hline $\mathrm{L}^{*}{ }_{\mathrm{OEt}} \mathrm{SnCl}(6)$ & - & - & - & - & + & $\mathrm{NC}$ & + & + & + & + & + & $\mathrm{NC}$ \\
\hline $\mathrm{LOEt}_{\mathrm{O}} \mathrm{SnPh}_{3}(7)$ & - & - & - & - & $\mathrm{NC}$ & $\mathrm{NC}$ & - & + & + & + & $\mathrm{NC}$ & $\mathrm{NC}$ \\
\hline $\mathrm{L}^{*}{ }_{\mathrm{OEt}} \mathrm{SnPh}_{3}(\mathbf{8})$ & - & - & - & + & + & + & + & + & + & + & + & + \\
\hline
\end{tabular}

In the present study a series of new four-and six-coordinated organotin complexes containing the oxygen tripodal ligand $\left[\left(\eta^{5}-\mathrm{C}_{5} \mathrm{R}_{5}\right) \mathrm{Co}\left\{\mathrm{P}(\mathrm{OEt})_{2} \mathrm{O}\right\}_{3}\right]^{-},\left\{\mathrm{R}=\mathrm{H},\left(\mathrm{Lott}^{-}\right)(3) ; \mathrm{R}=\mathrm{Me}\left(\mathrm{L}^{*}{ }_{\mathrm{OEt}}{ }^{-}\right)\right\}$(4) (Klaui, 1979; Roman et al., 1986; Klaui et al., 1987; Klaui et al., 1997) were studied with regard to their genotoxic and cytotoxic potential against human peripheral lymphocytes. In order to investigate their potential, the corresponding precursors, inorganic and organic ones, were studied as well. It should be noted, that since the introduction of the Klaui's oxygen tripodal ligand to a tin(II) and (IV) metal centre no genotoxic or cytotoxic study has been ever reported about this class of compounds while the work of Lloyd et al. (2006) emphasized on the synthesis and characterization of six-coordinate organotin(IV) complexes with the [( $\eta^{5}$ $\left.\left.\mathrm{C}_{5} \mathrm{R}_{5}\right) \mathrm{Co}\left\{\mathrm{P}(\mathrm{OMe})_{2} \mathrm{O}\right\}_{3}\right]^{-},\left\{\mathrm{R}=\mathrm{H},\left(\right.\right.$ Lome $\left.^{-}\right)$and $\left.\left(\mathrm{LoEt}^{-}\right)\right\}$ligands.

In a previous study, where various inorganic and organic tin(II) and tin(IV) salts were tested for possible genotoxic and cytotoxic activity, a lack of genotoxicity was revealed, while they were cytotoxic at several concentrations in the absence of metabolic activation (Damati et al., 2014). A low toxicity of inorganic tin forms towards microorganisms was reported, while organotin compound's toxicity was related to their lipophilicity (Cima et al., 2003). Trisubstituted $\left(R_{3} S n X\right)$ organotins appeared to be more toxic than disubstituted $\left(R_{2} S n X_{2}\right)$ and monosubstituted $\left(R S n X_{3}\right)$ compounds, while the anion $\left(X^{-}\right)$seemed to have little influence on the toxicity of the tin compound (Gadd, 2000). Furthermore it was reported that tributyltin and triphenyltin compounds showed higher toxicities against the red killifish Oryzias latipes among 29 
organotin compounds, while their toxicities did not depend upon their hydrophobic character (Nagase et al., 1991). In the meantime organotins are regarded as membrane permeable because of their lipophilicity and thus the possible site of their action may be the cytoplasmic membrane (Florea and Busselberg, 2006).

The present results indicate that the precursors $\mathrm{SnCl}_{2} \bullet 2 \mathrm{H}_{2} \mathrm{O}, \mathrm{NaLoEt}$ and NaL ${ }^{*}$ oEt used to synthesize the new organotin compounds were not genotoxic, while $\mathrm{NaLot}_{\text {and }}$ and $\mathrm{N}^{*}$ oet expressed a cytotoxic potential above the concentration of $20 \mu \mathrm{M}$. However, $\mathrm{Ph}_{3} \mathrm{SnCl}$ was highly cytotoxic even from the concentration of $5 \mu \mathrm{M}$. In the meantime at the concentration of $1 \mu \mathrm{M}$ did not increase the frequency of MN compared to the control. It must be noted that $\mathrm{Ph}_{3} \mathrm{SnCl}$ was genotoxic against Salmonella typhimurium, Escherichia coli and Bacillus subtilis (Hamasaki et al., 1992; Hamasaki et al., 1993), while trimethyl tin chloride induced $\mathrm{MN}$ and chromosome aberrations in human lymphocytes (Ghosh et al., 1990; Ghosh et al., 1991).

The LoEt $\mathrm{SnCl}$ compound appeared slightly genotoxic inducing statistically significant increased $\mathrm{MN}$ frequencies at the highest concentration, while its cytotoxicity represented the one expressed by its precursor NaLoEt. The $\mathrm{L}^{*}{ }_{\mathrm{OEt}} \mathrm{SnCl}$ complex was moderately genotoxic as induced statistically significant increased micronuclei frequencies at the concentration of $50 \mu \mathrm{M}$. Moreover our results show that $\mathrm{L}^{*}{ }_{\mathrm{OEt}} \mathrm{SnCl}$ complex was cytotoxic at all tested concentrations. The data indicate that the presence of the methyl group instead of hydrogens in the cyclopentadienyl ring renders $\mathrm{L}^{*}{ }_{\mathrm{OE}} \mathrm{tSnCl}$ more cytotoxic. In addition it was reported that tin (IV) chloride was not cytotoxic towards human lymphocytes (Damati et al., 2014). The above indicate that the presence of methyl group may induce genotoxic as well as cytotoxic effects to human cells.

The tested compounds (7) and (8) containing the characteristic $-\mathrm{Ph}_{3} \mathrm{Sn}$ moiety were highly cytotoxic; a result which is in accord with our observations about the extremely high toxicity of the $\mathrm{Ph}_{3} \mathrm{SnCl}$ precursor. Triphenyl tin chloride was reported to induce chromosome aberrations in Chinese hamster ovary cells (CHO-K1) (Sasaki et al., 1993). In the meantime, it was suggested that some organotin compounds are able to inducing aneuploidy in human peripheral lymphocytes in vitro, probably by affecting spindle function (Jensen et al., 1991).

Our data could be summarized as follow:

Regarding the mutagenic potential, $\mathrm{SnCl}_{2} \bullet 2 \mathrm{H}_{2} \mathrm{O}(\mathbf{1}), \mathrm{NaLOEt}(3)$ and $\mathrm{NaL}^{*}{ }_{\mathrm{OEt}}(\mathbf{4})$ revealed not to be genotoxic, while $\mathrm{LoEt}_{\mathrm{OnCl}}(\mathbf{5})$ was genotoxic above $50 \mu \mathrm{M}$ and $\mathrm{L}^{*}{ }_{\mathrm{OEt}} \mathrm{SnCl}(6)$ above $20 \mu \mathrm{M}$. Complex $\mathrm{LOEt}_{\mathrm{SnPh}}(\mathbf{7})$ was not genotoxic up to $20 \mu \mathrm{M}$ compared to $\mathrm{L}^{*}{ }_{\mathrm{OEt}} \mathrm{SnPh}_{3}(8)$ that was genotoxic from the concentration of 20 $\mu \mathrm{M}$.

Regarding the cytotoxic potential, $\mathrm{SnCl}_{2} \bullet 2 \mathrm{H}_{2} \mathrm{O}$ (1) did not exert any cytotoxic effect, while NaLoet (3), $\mathrm{NaL}^{*}{ }_{\mathrm{OEt}}(\mathbf{4})$ and $\mathrm{L}_{\mathrm{OEt}} \mathrm{SnCl}(\mathbf{5})$ were cytotoxic above the concentration of $20 \mu \mathrm{M}$. L* ${ }_{\mathrm{OEt}} \mathrm{SnCl}(6), \mathrm{L}_{\mathrm{OEt}} \mathrm{SnPh}_{3}(\mathbf{7})$ and $\mathrm{L}^{*}{ }_{\mathrm{OEt}} \mathrm{SnPh}_{3}(\mathbf{8})$ exerted various levels of cytotoxicity including lethal effects at the tested concentrations. In the meantime, $\mathrm{Ph}_{3} \mathrm{SnCl}$ (2) was extremely toxic to lymphocytes except at the concentration of $1 \mu \mathrm{M}$.

\section{Conclusions}

In conclusion the data of the present paper regarding the total genotoxic and cytotoxic potential of the tested chemicals, in the specific concentrations and experimental conditions, suggest that the compounds NaLoet (3), NaL*oet (4) and $\mathrm{L}_{\mathrm{OEt}} \mathrm{SnCl}(5)$ are very promising and could be potentially used for further biological applications.

\section{References}

Appel K.E. (2004), Organotin compounds: Toxicokinetic aspects, Drug Metab Rev, 36, 763-786.

Basu Baul T.S. (2008), Antimicrobial activity of organotin (IV) compounds: a review, Appl Organomet Chem, 22,195204. 
Bonassi, S., Michael Fenech, M., Lando, C., Lin, Y-P., Ceppi, M., Chang, W.P., Holland, N., Kirsch-Volders, M. et al. (2001), Human MicroNucleus Project: International Database. Comparison for Results With the CytokinesisBlock Micronucleus Assay in Human Lymphocytes: I. Effect of Laboratory Protocol, Scoring Criteria, and Host Factors on the Frequency of Micronuclei. Environmental and Molecular Mutagenesis. 37, 31-45.

Chasapis C.T., Hadjikakou S.K., Garoufis A., Hadjiliadis N., Bakas T., Kubicki M. and Ming Y. (2004), Organotin(IV) derivatives of L-cysteine and their in vitro anti-tumor properties, Bioinorg Chem Appl, 2, 43-54.

Cima F., Craig P.J. and Harrington C.F. (2003), Organotin compounds in the environment, In: Organometallic Compounds in the Environment Craig, P.J. (Ed.), John Wiley and Sons, Chichester.

Clare G., Lorenzon G., Akhurst L., Marzin D., van Delft J., Montero R., Botta A., Bertens A., Cinelli S., Thybaud V. and Lorge E. (2006), SFTG International collaborative study on the in vitro micronucleus test. II. Using human lymphocytes, Mutat Res, 607, 37-60.

Damati A., Vlastos D., Philippopoulos A.I. and Matthopoulos D.P. (2014), Inorganic tin compounds do not induce micronuclei in human lymphocytes in the absence of metabolic activation, Drug ChemToxicol, 37, 1-4.

Dopp E., Hartmann L.M., Florea A.M., Rettenmeier A.W. and Hirner A.V. (2004), Environmental distribution, analysis, and toxicity of organometal(loid) compounds, Crit Rev Toxicol, 34, 301-333.

Fenech M., Chang W.P., Kirsch-Volders M., Holland N., Bonassi S. and Zeiger E. (2003), HUMN project: detailed description of the scoring criteria for the cytokinesis-block micronucleus assay using isolated human lymphocyte cultures, Mutat Res, 534, 65-75.

Filippou A.C., Portius P., Kociok-Köhn G. and Albrecht V. (2000), Oxidation of germanium(II) azides with $\mathrm{HN}_{3}$ : A convenient route to six-co-ordinate triazidogermanium(IV) compounds, J Chem Soc, Dalton Trans, 1759-1768.

Florea A.M. and Busselberg D. (2006), Occurrence, use and potential toxic effects of metals and metal compounds, BioMetals, 19, 419-427.

Gadd G.M. (2000), Microbial interactions with tributyltin compounds: Detoxification, accumulation, and environmental fate, Sci Total Environ, 258, 119-127.

Ghosh B.B., Talukder G. and Sharma A. (1991), Frequency of chromosome aberrations induced by trimethyltin chloride in human peripheral blood lymphocytes in vitro: Related to age of donors, Mech Ageing Dev, 57, 125-137.

Ghosh B.B., Talukder G. and Sharma A. (1990), Frequency of micronuclei induced in peripheral lymphocytes by trimethyltin chloride, Mutat Res, 245, 33-39.

Gielen M., Biesemans M. and Willem R. (2005), Organotin compounds: from kinetics to stereochemistry and antitumor activities, Appl Organomet Chem, 19, 440-450.

Gielen M. (2003), An overview of forty years organotin chemistry developed at the Free Universities of Brussels ULB and VUB, J Braz Chem Soc, 14, 870-877.

Government of Canada. (2010), Chemical Substances, Organotin Substances. Available: http://www.chemicalsubstanceschimiques.gc.ca/fact-fait/organo-eng.php. (accessed 4.10.2011)

Greenwood N.N. and Earnshaw A. (1997), Chemistry of the Elements, Second Edition, Butterworth-Heinemann, Oxford.

Hadjikakou S.K. and Hadjiliadis N. (2009), Antiproliferative and anti-tumor activity of organotin compounds, Coord Chem Rev, 253, 235-249.

Hamasaki T., Sato T., Nagase H and Kito H. (1993), The mutagenicity of organotin compounds as environmental pollutants, Mutat Res, 300, 265-271.

Hamasaki T., Sato T., Nagase H. and Kito H. (1992), The genotoxicity of organotin compounds in SOS chromotest and rec-assay, Mutat Res, 280, 195-203.

Jensen K.G., Andersen O. and Ronne M. (1991), Organotin compounds induce aneuploidy in human peripheral lymphocytes in vitro, Mutat Res, 246,109-112.

Khan N., Farina Y., Mun L.K., Rajab N.F. and Awang N. (2014), Triorganotin(IV) complexes with o-substituted arylhydroxamates: Synthesis, spectroscopic characterization, $\mathrm{X}$-ray structures and in vitro cytotoxic activities, $J$ Organomet Chem,763, 26-33.

Kläui W., Asbahr H-O., Schramm G. and Englert U. (1997), Tris-chelating oxygen ligands: new synthetic routes to sterically demanding ligands, Chemische Berichte, 130, 1223-1229. 
Kläui W., Müller A., Eberspach W., Boese R. and Goldberg I. (1987), Crystal structure and coordination chemistry of the pentane-soluble sodium salt of an oxygen tripod ligand, J Am Chem Soc, 109, 164-169.

Kläui W. (1979), $\left[\left(\mathrm{C}_{5} \mathrm{H}_{5}\right) \mathrm{Co}\left\{\mathrm{P}(0)\left(\mathrm{OC}_{2} \mathrm{H}_{5}\right)_{2}\right\}_{3}\right]^{-}$: A convenient synthesis of an organometallic tripodal ligand and its reactivity towards the main group III cataions, Z Naturforsch, 34b,1403-1407.

Lloyd N.C., Nicholson B.K. and Wilkins A.L. (2006), Six-coordinate organotin(IV) complexex formed using the Klaui ligands; [CpCo $\left.\left\{\mathrm{P}_{(\mathrm{OR}}\right)_{2} \mathrm{O}_{3}\right] \mathrm{SnR}_{3}{ }_{n} \mathrm{Cl}_{n}$, J Organomet Chem, 691, 2757-2766.

Nagase H., Hamasaki T., Sato T., Kito H., Yoshiokat Y. and Ose Y. (1991), Structure-activity relationships for organotin compounds on the red killifish Oryzias latipes, Appl Organomet Chem, 5, 91-97.

OECD (2014), Test No. 487: In Vitro Mammalian Cell Micronucleus Test, OECD Guidelines for the Testing of Chemicals, Section 4, OECD Publishing. DOI: 10.1787/9789264224438-en.

Penninks A.H. and Seinen W. (1984), Mechanisms of dialkyltin induced immunopathology, Vet Q, 6, 209-215.

Pizarro A.M., Habtemariam A. and Sadler P.J. (2010), Activation Mechanisms for Organometallic Anticancer Complexes, Top Organomet Chem, 32, 21-56.

Román E.E., Tapia C.F. and Hernández M.S. (1986), A novel access to the anionic permethylatedfac-tripod ligand $\left[\mathrm{C}_{5} \mathrm{Me}_{5} \mathrm{Co}\left[\mathrm{P}(\mathrm{O})(\mathrm{OEt})_{2}\right]_{3}\right]^{-}$and its derived trinuclear and binuclear complexes, Polyhedron, 5, 917-90.

Sasaki Y.F., Yamada H., Sugiyama C. and Kinae N. (1993), Increasing effects of tri-n-butyltins and triphenyltins on the frequency of chemically induced chromosome aberrations in cultured Chinese hamster cells, Mutat Res, 300, 5-14.

Shpakovsky D.B., Banti C.N., Mukhatova E.M., Gracheva Y.A., Osipova V.P., Berberova N.T., Albov D.V., Antonenko T.A., Aslanov L.A., Milaeva E.R. and Hadjikakou S.K. (2014), Synthesis, antiradical activity and in vitro cytotoxocity of novel organotin complexes based on 2,6-di-tert-butyl-4-mercaptophenol, Dalton Transact, 43, 6880-6890.

Stivaktakis P., Vlastos D., Giannakopoulos E. and Matthopoulos D.P. (2010), Differential micronuclei induction in human lymphocyte cultures by imidacloprid in the presence of potassium nitrate, The Scientific World Journal, 10, 80-89.

Surrallés J., Xamena N., Creus A., Catalan J., Norppa H. and Marcos R. (1995), Induction of micronuclei by five pyrethroid insecticides in whole-blood and isolated human lymphocyte cultures, Mutat Res, 341, 169-184.

Tabassum S. and Pettinari C. (2006), Chemical and biotechnological developments in organotin cancer chemotherapy, J Organomet Chem, 691, 1761-1766.

Whalen M.M., Loganathan B.G., and Kannan K. (1999). Immunotoxicity of environmentally relevant concentrations of butyltins on human natural killer cells in vitro, Environ Res, 81, 108-116.

Zhao B., Shan X.M., Xu L., Zhang W.D. and Xiang G.Y. (2014), Novel mixed ligand di-n-butyltin(IV) complexes derived from acylpyrazolones and fluorinated benzoic acids: Synthesis, characterization, cytotoxicity and the induction of apoptosis in Hela cancer cells, Eur J Med Chem, 76, 87-97. 